\title{
A new Pre-Pottery Neolithic site in Southeastern Turkey: Ayanlar Höyük (Gre Hut)
}

\author{
Bahattin Çelik \\ Department of Archeology, University of Ardahan, Ardahan, TR \\ bahattincelik@ardahan.edu.tr
}

\begin{abstract}
Ayanlar Höyük (Gre Hut), located 30km west of Sanluurfa, was discovered during surface surveys conducted in 2013. Ayanlar Höyük dated to the Pre-Pottery Neolithic Period, is a largescale mound like Göbekli Tepe and Karahan Tepe, covering an overall surface area of 14 hectares. It was learned recently that three artefacts dated to the Pre-Pottery Neolithic period which are held by Şanhurfa Museum were brought from Ayanlar Höyük. The artefacts in Şanlurfa Museum and the finds recovered from Ayanlar Höyük during a surface survey have been identified as having characteristics similar to those from Körtik Tepe, Göbekli Tepe, Nevali Çori and Karahan Tepe. Consequently, Ayanlar Höyük should be dated between the early Pre-Pottery Neolithic Period B (EPPNB) and the mid-Pre-Pottery Neolithic Period B (MPPNB).
\end{abstract}

KEY WORDS - Göbekli Tepe; Karahan Tepe; animal sculpture; decorative stone vessel; Pre-Pottery Neolithic Period

\section{Novo najdišče predkeramičnega neolitika na jugovzhodu Turčije: Ayanlar Höyük (Gre Hut)}

IZVLEČEK - Najdišče Ayanlar Höyük (Gre Hut), ki je bilo odkrito med terenskimi pregledi leta 2013, se nahaja ok. 30km zahodno od Sanluurfe. Ayanlar Höyük je veliko večslojno (tell) naselje, podobno najdiščema Göbekli Tepe in Karahan Tepe,ki se razteza na skupni površini 14 hektarjev in jo datiramo $v$ obdobje predkeramičnega neolitika. Nedavno je bilo ugotovljeno, da so bili trije predmeti, ki datirajo $v$ čas predkeramičnega neolitika in se zdaj nahajajo v muzeju v Şanlurfi, dejansko izvirajo iz najdišča Ayanlar Höyük. Ti predmeti kot tudi najdbe, ki smo jih pridobili pri našem terenskem pregledu, imajo podobne značilnosti kot najdbe iz najdišč Körtik Tepe, Göbekli Tepe, Nevali Cori in Karahan Tepe. Na podlagi teh zbirov sklepamo, da lahko Ayanlar Hövük datiramo v čas med zgodnjim predkeramičnim neolitikom B (EPPNB) in srednjim predkeramičnim neolitikom B (MPPNB).

KLJUČNE BESEDE - Göbekli Tepe; Karahan Tepe; živalske skulpture; okrašene kamnite posode; predkeramični neolitik

\section{Introduction}

Ayanlar Höyük ${ }^{1}$ was first discovered during surface surveys conducted in 2013 (Güler, Celik 2015.8384, Res. 11-13; Celik 2014a.19; 2014b.318). Ayanlar Höyük is the largest mound from Neolithic period known in the region and is located west of Şan- liurfa (Map 1). As a result of the research conducted in the south-eastern part of Ayanlar Höyük, 6 settlements with characteristics that can be dated to the Neolithic Period were determined at distances ranging from 2 to $7 \mathrm{~km}$ (Celik 2014a.19; 2014b.317-318;

1 Ayanlar Höyük is called as 'Gre Hut' by the local community. 
2015a.446-447; 2015b.356-357; Güler, Celik 2015.82-83). ${ }^{2}$ These are mostly small-scale settlements. It is estimated that the mound of Ayanlar - the eastern, western and northern sections of which have yet to be investigated - was a big centre in its region. During the studies conducted in the region in 2015 , it was understood that the three artefacts (Ercan, Celik 2013.Res. 1-3, Fig. 1-2) brought to the Şanliurfa Museum in 2013 and dated to the Pre-Pottery Neolithic Period were unearthed from Ayanlar Höyük3. Ayanlar Höyük is the third largest mound dated to the Pre-Pottery Neolithic Period after the pre-

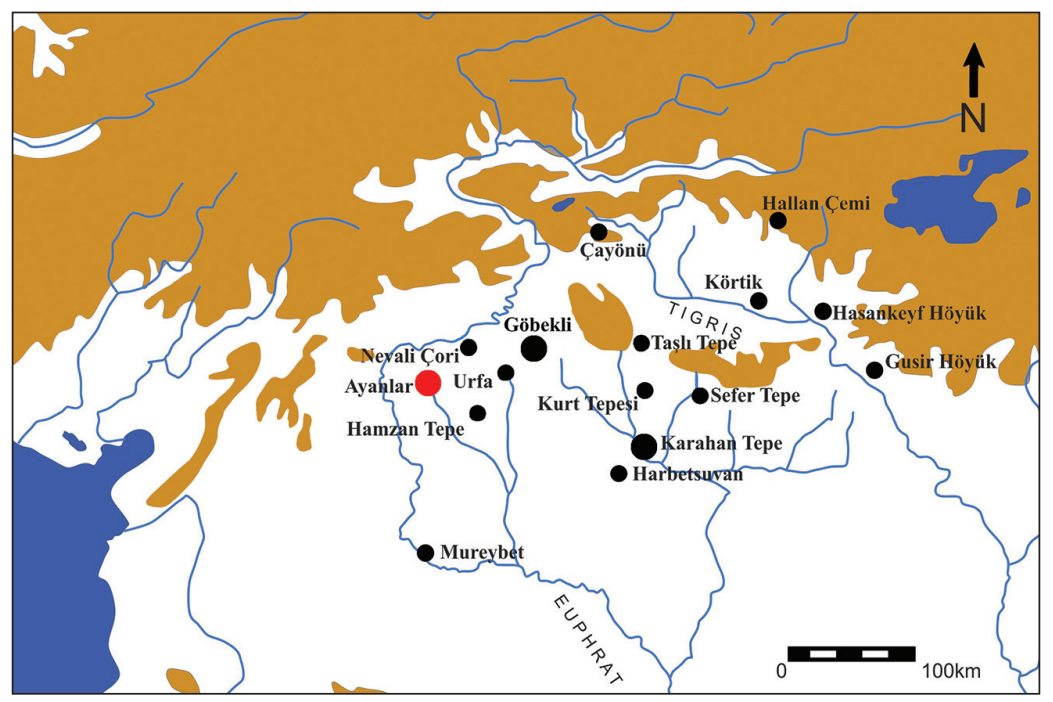

Map 1. Ayanlar Höyük and other Neolithic centres located in the region (created by 0 . Aras). viously known Göbeklitepe and Karahan Tepe in the region. With the discovery of Ayanlar Höyük, which stands out with its area of approx. 14ha (Güler, Celik 2015.Fig. 13; Celik 2015a.447; 2014b.318; $2014 a$. 19; 2015b.357) 4 , the number of large-scale settlements dating to the Pre-Pottery Neolithic Period of the region now stands at three. This discovery demonstrates once again that multiple large-scale settlements existed in the region during the Neolithic Period.

\section{Location}

The settlement is located partially underneath the northern part of Ayanlar Mahallesi, which is located within the boundaries of Karaköprü county, about $30 \mathrm{~km}$ west of Sanliurfa (Celik 2015a.447)5 by the motorway route (Fig. 1). The settlement was first discovered during a surface survey conducted in 2013 (Güler, Çelik 2015.83-84; Çelik 2015a. 447448; 2014a.19).

Ayanlar Höyük's lies 733 metres a.s.l.. The mound is $250 \times 300 \mathrm{~m}$ and presents a broad and shallow structure which contains six small hillocks (Fig. 2). One of these hillocks contains a small burial ground thought to be in use recently and during the Byzantine period (Celik 2015a.448). The mound is covered with cultivated soil approx. $10 \mathrm{~m}$ above the bedrock. Pistachio orchards cover the land over the mound, as arable land is scarce in the region. A north-south road cuts through the centre of the mound, and an asphalt road runs on the southern part of the mound (Fig. 2).

The geological structure of the region comprises entirely calcareous stratigraphy. However, there is a high plateau $2 \mathrm{~km}$ east of the mound with massive outcrops of basalt (Güler, Çelik 2015.84; Celik 2015b.357). This region is in the form of a basalt-covered plateau known as Mt. Kaşmer, with an elevation of approx. 910 metres a.s.l. Flintstone deposits are not encountered in the vicinity of the settlement site. Therefore, it is thought that the inhabitants obtained their flint from another region.

Slightly inclined calcareous plateaus extend to the south, west and north of Ayanlar Höyük. An investigation of the geographical location of the mound shows that the surrounding area has generally

2 Five Neolithic settlements were identified in the previous publications. Thereafter, one more Neolithic settlement is added to such settlements based on the analyses on the finds, increasing the total number of Neolithic settlements to six.

3 No settlement from the Neolithic period has been found at İnlice village, the site where three artefacts are thought to have been discovered during surveys carried out in 2015. Interviews with İnlice villagers revealed that villagers were employed at Ayanlar village and that such artefacts might have been brought to the village from there (private interview with Mehmet Kaçmaz, 14.01.2015).

4 In previous publications, the surface area of the settlement was estimated at 17 ha by including the pool groups carved into the bedrock around the mound. In the other publications, however, such pool groups are not included, and only the area of soil covering land on the mound is calculated.

5 Inadvertently specified as $27 \mathrm{~km}$ in one of the publications on Ayanlar Höyük. 
turned into barren and rocky terrain due to soil erosion, with very scarce arable land. In addition, it is also reasonable to mention that the Ayanlar site was founded close to water springs. As a matter of fact, the existence of a cave carved some $30 \mathrm{~m}$ into the bedrock during early or middle Byzantine period to obtain water has been discovered in a valley south of the settlement (Celik 2014b.318, Res. 14). This valley is also the origin of a stream bed through which seasonal rainwater flows down to the Harran Plain (Map 1).

Thus far, only the south-eastern section of Ayanlar Höyük has been investigated. Approx. seven sites were identified in this area (Celik 2015a.446-447; $2014 b .317-318)^{6}$; six are dated to the Neolithic period. Four settlements - Hasan Sirtı (Celik 2015b.35, Pl. 4.i-l), Ömer Altundağ Tarlası (Celik 2015b.357, Pl. 4.e-h), Cillo Mevkii 1 (Celik 2015a.446; $2015 b$. 356, Pl. 3.a-k) and Cillo Mevkii 2 (Celik 2015a.446; 2015b.356, Pl. 3.l-t) - are characterised as hillside settlements. The remaining two settlements, Domuzcurnu Tepesi (Celik 2015a.447, Fig. 17) and Nebi Tarlası (Celik 2015a.447), on the other hand, were founded on slightly higher hills. Out of these six Neolithic settlements, only Domuzcurnu Tepesi is reliably dated to the Pre-Pottery Neolithic period (Celik 2015b.356, Pl. 3.u-z). Although several finds from the Pre-Pottery Neolithic were recovered from other settlements, such sites tend to present the characteristics of the Pottery Neolithic.

A similar fact concerning the Neolithic sites located south of Ayanlar Höyük also applies to Sefer Tepe and the surrounding area (Güler et al. 2013.297, Map. 1). This suggests that Ayanlar Höyük might also be a site that should be characterised as a largescale centre like Sefer Tepe (Atakuman 2014.9, 26; Benz, Bauer 2014.15, 18).

Ayanlar Höyük is another settlement founded on bedrock, just like the Pre-Pottery Neolithic sites in the region, such as Karahan Tepe, Nevali Çori, Göbekli Tepe, Şanlıurfa-Yeni Mahalle, Harbetsuvan Tepesi, Kurt Tepesi, Taşlı Tepe, Sefer Tepe and Hamzan Tepe (Celik 2014a.22). The settlement is half a day's walk to several Pre-Pottery Neolithic sites in the region. The settlement is some $45 \mathrm{~km}$ from Göbekli Tepe, $25 \mathrm{~km}$ from Nevali Çori, $30 \mathrm{~km}$ from Şanliurfa-Yeni Mahalle and $35 \mathrm{~km}$ from Hamzan Tepe (Map 1).

\section{Ayanlar Höyük finds}

The surface surveys conducted in Ayanlar Höyük led to the identification of two periods, the Pre-Pottery Neolithic period and Byzantine period. The early and middle Byzantine period is rather confined to a small area below and around the village (Fig. 2.6). The ceramic finds from this period tend to be concentrated around the village. Headstones and a village cemetery dating to the early Byzantine period were discovered on hill 1 of the mound (Fig. 2.1). Flint and obsidian tools, top and bottom grindstones, pestles and stone axes were discovered in all other areas of the mound.

\section{Architectural finds}

A harvested stone from Pre-Pottery Neolithic period was discovered in the village cemetery on hill 1 of Ayanlar Höyük (Figs. 2.1 and 3). Stones similar to this one were also discovered at Göbekli Tepe (Schmidt 2010.Fig. 21) and Karahan Tepe (Fig. 4). This is a shaped stone that could be used as a window or door. This stone is believed to be a porthole observed inside cult buildings (Schmidt 2010.250).

A harvested stone cube used in the village was also identified (Fig. 5). In terms of dimensions, this cube is similar to the cubes from the Göbekli Tepe Layer II, which are thought to have been used mainly in feasting ceremonies (Dietrich et al. 2012.687, Fig. 11).

\section{Small finds}

Most of the small finds recovered from Ayanlar Höyük consists of flint cores, chips, blades and debitage (Fig. 6.a-i). No Neolithic ceramics were found. A very small number of obsidian finds was recovered from the settlement in the form of chips and debitage. Moreover, Byblos- and Nemrik-type arrowheads, a stone chisel, end-scraper and hammer were discovered amongst the flint finds (Fig. 6.j-n). If we consider the flint tools as a whole, we observe types of tools peculiar to the Pre-Pottery Neolithic period from topological aspect. In particular, Byblos-type and Nemrik-type flint arrowheads were also found in the region at Göbekli Tepe (Beile-Bohn et al. 1998. Abb. 23.3; Schmidt 1988. Fig. 8; 2001.52, Fig. 10/3, 11/5), Şanlıurfa-Yeni Mahalle (Celik 2000.Fig. 5.1; 2007.Fig. 20/6; 2011a.Fig. 20), Hamzan Tepe (Çelik

6 The studies conducted at the Yoğunburç Oç̧ik Mevkii site, which had previously been dated to the Neolithic, revealed that the ceramics are actually from the Chalcolithic and Byzantine periods. 
2010.Fig. 9.5, 7,10,17,18) and Karahan Tepe (Celik 2011b. Fig. 18 type I-1).

The other stone finds recovered from the site are top and bottom grindstones (Fig. 7), pestles (Fig. 6 . $\mathrm{r}-\mathrm{u}$ ), a hatchet made of pebble (Fig. 60), stone dishes (Figs. 8 and 6.p), a decorated stone vessel fragment (Fig. 9.a-b), a stone cube (Fig. 8) and a piece of a sculpture thought to be the head of a leopard (Fig. 10.a-d).

A decorated stone vessel (Fig. 9.a-b), (Ercan, Celik 2013.Pic. 1a-d, Ciz. 1a-d) and a stone dish (Fig. 8), (Ercan, Celik 2013.Pic 2, Ciz. 2) discovered at Ayanlar Höyük and currently on display at Şanliurfa $\mathrm{Mu}$ seum of Archeology present great similarities with the finds recovered from Körtik Tepe site (Özkaya, San 2007.21-36). Moreover, a fragment of a sculpture of dimensions thought to be a leopard on display at the same museum was also recovered from Ayanlar Höyük (Fig. 10.a-d). All the aforementioned artefacts were considered to be recovered from İnlice (Kurtharabesi) village, located approx. $10 \mathrm{~km}$ south of Ayanlar Höyük. However, the surface survey carried out at this village revealed no signs of settlement. It was later ascertained that such finds had been transported to İnlice village from Ayanlar Höyük by a villager. 7

Groups of hollows carved into the bedrock were encountered on the rocky terrain located south of the mound (Fig. 11). Similar groups, thought to be a technique employed for constructing pools, are recognised and known in the region from Göbekli Tepe (Schmidt 2007.Fig. 5), Karahan Tepe (Celik 2011b.Fig. 5; 2015.Fig. 27) and Hamzan Tepe (Güler, Celik 2015.Res. 15; Celik 2015.Fig. 23). Another interesting find discovered in the graveyard on Ayanlar Höyük is a stone fragment considered to be an entrance gate or window to cult areas, maybe a porthole (Fig. 3). A similar find was also recovered from the surface of Karahan Tepe (Fig. 4). Moreover, identical finds were also encountered at Göbekli Tepe (Schmidt 2010.250-252, Fig. 21, 23-24). Such stone finds were usually recovered from settlements where cult buildings are present (Schmidt 2010. 250, Fig. 23). Thus far, no 'T'-shaped pillars have been discovered at Ayanlar Höyük; however, the discovery of pillar pedestals at the settlement increases the probability of finding ' $\mathrm{T}$ '-shaped pillars here. Another artefact that supports this fact is the sculpture fragment thought to depict the head of a leopard (Ercan, Celik 2013.21, 35-36, Pic. 3a-d). This fragment is very similar to finds recovered from Göbekli Tepe (Schmidt 2007.Fig. 23) and Nevali Çori (Hauptmann 2007.Fig. 20). Moreover, such sculptures are generally found in cult buildings (Schmidt 2010. 251, Fig. 23).

\section{Conclusion}

The stream that flows from the basin area of Mount Kaşmer, located east of Ayanlar Höyük, featuring a basaltic structure is known as Karakoyun Stream (Celik 2007.15, Fig. 3; 2011a.139, Fig. 3) ${ }^{8}$. In the Neolithic, this stream, the course of which was altered in the Byzantine period, flowed just upstream from the Şanlıurfa-Yeni Mahalle (Balıklıgöl Höyüğü) settlement (Celik 2007.165-178; 2011a. 139-164). Therefore, the valley through which the Karakoyun Stream flows probably acted as a linking route between Şanlıurfa-Yeni Mahalle Höyük and Ayanlar Höyük.

The three artefacts (Ercan, Celik 2013.13-24) identified as from Ayanlar Höyük before being delivered to Şanliurfa Museum are important, as such artefacts demonstrate the possibility for the presence of cult buildings at this settlement. In particular, the sculpture fragment depicting the head of a lion/leopard among such artefacts greatly resembles the alto relievo lion located in Building $C$ at Göbekli Tepe (Schmidt 2011.48, Fig. 28). Furthermore, the sculpture also has characteristics similar to those of the lion reliefs in the Lion Building (Schmidt 1998.3031, Abb. 9-10).

The recovery of the decorated stone vessel from Ayanlar Höyük, which is currently on display at Şanliurfa Museum, is also important because this is an indication that the burial traditions practiced at Ayanlar Höyük had characteristics similar to those at Körtik Tepe. In addition, although only four or five decorated stone vessel fragments have been recovered from the excavations at Göbekli Tepe, an almost intact stone vessel was recovered from Ayanlar Höyük. The presence of all these finds suggests that Ayanlar Höyük might be a large-scale settlement that will yield substantial finds.

So far, the finds recovered from Ayanlar Höyük indicate that the settlement has characteristics iden-

7 Private interview with Abdulkadir Kaçmaz on 16.01.2015, who delivered 3 artefacts to Şanlıurfa Museum. 
tical with Layer II of Göbekli Tepe. However, taking into consideration the $10 \mathrm{~m}$ of cultivated soil covering the settlement, it is highly possible that similar finds from Layer III of Göbekli Tepe will be found. In conclusion, the abundance and high-quality of the finds from Ayanlar Höyük resembling the finds from Göbekli Tepe and Karahan Tepe indicates that this settlement was an extensive Neolithic centre. Moreover, the surface area of the settlement, some 14ha, and the presence of small hills thereon, as at Göbekli Tepe and Karahan Tepe, shows that Ayanlar Höyük was an extensive settlement during the Neoli- thic period, like Göbekli Tepe and Karahan Tepe. Ayanlar Höyük should be dated between the early Pre-Pottery Neolithic B period (EPPNB) and mid-PrePottery Neolithic period (MPPNB) in the light of the finds recovered there.

We would like to express our gratitude to the Turkish Historical Society, to Ahmet Esref Fakıbaba, the former Mayor of Sanlurfa, and to Mehmet Ekinci, Mayor of Sanlurfa Eyyübiye Borough for their support.

\section{References}

Atakuman C.. 2014. Architectural Discourse and Social Transformation During the Early Neolithic of Southeast Anatolia. Journal World Prehistory 27: 1-42.

Beile-Bohn M., Gerber C., Morsch M. and Schmidt K. 1998. Neolithische Forschungen in Obermesopotamien. Gürcütepe und Göbekli Tepe. Istanbuler Mitteilungen 48: 5-78.

Benz M., Bauer J. 2013. Symbols of Power Symbols of Crisis? A Psycho-Social Approach to Early Neolithic Symbol Systems. Neo-Lithics 2(13): 11-24.

Celik B. 2000. An Early Neolithic Settlement in the Center of Sanliurfa, Turkey. Neo-Lithics 2(3): 4-6.

2006. A New Pre-Pottey Neolithic Site in Southeastern Turkey: Sefer Tepe. Neo-Lithics 1(06): 23-25.

2007. Şanlıurfa-Yeni Mahalle, Balıklıgöl Höyüğü. Anadolu'da Uygarlığın Doğuşu ve Avrupa'ya Yayılımı. In M. Özdoğan, N. Başgelen (eds.), Türkiye'de Neolithic period, Yeni Kazular, Yeni Bulgular. Arkeoloji ve Sanat Yayınları. Istanbul: 165-178.

2010. Hamzan Tepe in the Light of New Finds. Documenta Preahistorica 37: 257-268.

2011a. Şanlıurfa-Yeni Mahalle. In M. Özdoğan, N. Başgelen and P. Kuniholm (eds.), The Neolithic in Turkey. New Excavation and New Research. Archaeology and Art Publication. Istanbul: 139-164.

2011b. Karahan Tepe: a new cultural centre in the Urfa area in Turkey. Documenta Praehistorica 38: 241-253.

2014a. Differences and Similarities between the Settlements in Şanlıurfa Region where "T" Shaped Pillars are Discovered. Türkiye Bilimler Akademisi Arkeoloji dergisi: 9-23. 2014b. Şanluurfa İi Merkez İlçesi Neolitik Çăg ve Öncesi Yüzey Araștırması, 2013. 32. Araștırma Sonuçları Toplantıs1, 02-06 Haziran 2014 Gaziantep, Yayin No 168-2, İsmail Aygül Ofset Matbaacıllk San. Tic. Ltd. Şti., 2. Cilt. Ankara: 311-328.

2015a. Neolithic Settlements of Şanliurfa in Southeastern Turkey. In. E. Laflı, S. Patacı (eds.), Recent Studies on the Archaeology of Anatolia. British Archaeological Reports IS 2750. Archaeopress. Oxford: 441-452.

2015b. New Neolithic cult centres and domestic settlements in the light of Urfa Region Surveys. Documenta Praehistorica 42: 353-264.

Dietrich 0., Heun M., Notrof J., Schmidt K. and Zarnkow M. 2012. The role of cult and feasting in the emergence of Neolithic communities. New evidence from Göbekli Tepe, south-eastern Turkey. Antiquity 86: 674-695.

Ercan M., Çelik B. 2013. Şanlıurfa Müzesi'nden Neolithic Döneme Ait Bir Grup Eser/A Group of Artifacts From Neolithic Period in Şanliurfa Museum. Anadolu/Anatolia 39: $13-54$.

Güler G., Çelik B. and Güler M. 2013. New Pre-Pottery Neolithic sites and cult centres in the Urfa Region. Documenta Praehistorica 40: 291-303.

Güler M., Çelik B. 2015. Şanlıurfa Bölgesi Neolithic Period Araştırmaları. Belgü 1(1): 75-102.

Hauptmann H., 2007. Nevali Çori ve Urfa Bölgesinde Neolitik Dönem. Anadolu'da Uygarlı̆̆ın Doğuşu ve Avrupa'ya Yayılımı. Türkiye'de Neolitik Dönem, Yeni Kazılar, Yeni Bulgular. In M. Özdoğan, N. Başgelen (eds.), Arkeoloji ve Sanat Yaymları. Dogu Kutuphanesi. Istanbul: 131-164.

Özkaya V., San 0. 2007. Körtik Tepe, Bulgular Işı̆ğında Kültürel Doku Üzerine Illk Gözlemler. Anadolu'da Uygar- 
lığın Doğuşu ve Avrupa'ya Yayılımı. Türkiye'de Neolithic period, Yeni Kazılar, Yeni Bulgular. In M. Özdoğan, N. Başgelen (eds.), Arkeoloji ve Sanat Yaymları. Dogu Kutuphanesi. Istanbul: 21-36.

Schmidt K. 1988. Nevali Çori: Zum Typenspektrum der Silexindustrie und der übrigen Kleinfunde. Anatolica 15: 161-201.

1998. Frühneolithische Tempel. Ein Forschungsbericht zum präkeramischen Neolithikum Obermesopotamiens. Mitteilungen der Deutschen Orient-Gesellschaft 130: 17-49.

2001. Göbekli Tepe, Southeastern Turkey. A Preliminary Report on the 1995-1999 Excavations. Paléorient 26 (1): 45-54.
2007. Göbekli Tepe. Anadolu'da Uygarlığın Doğuşu ve Avrupa'ya Yayılımı. Türkiye'de Neolitik Dönem, Yeni Kazilar, Yeni Bulgular. In M. Özdoğan, N. Başgelen (eds.), Arkeoloji ve Sanat Yayınları. Dogu Kutuphanesi. Istanbul: 115-129.

2010. Göbekli Tepe - the Stone Age Sanctuaries. New results of ongoing excavations with a special focus on sculptures and high reliefs. Documenta Praehistorica 37: 239-256.

2011. Göbekli Tepe. The Neolithic in Turkey. New Excavation and New Research. In M. Özdoğan, N. Başgelen and P. Kuniholm (eds.), The Neolithic in Turkey 2. The Euphrates Basin. New Excavations and New Research. Archaeology and Art Publication. Istanbul: 4183.

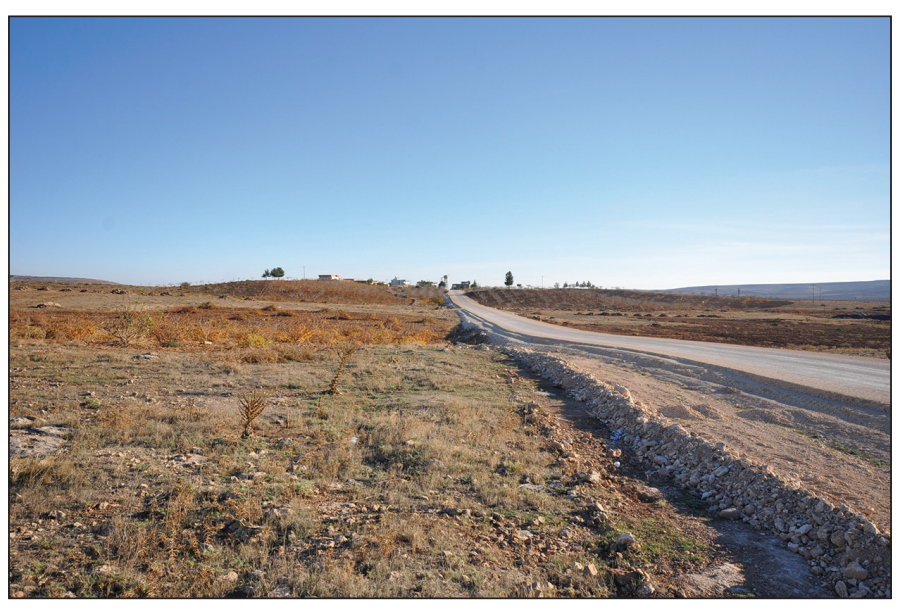

Fig. 1. View of Ayanlar Höyük from the North (photo by B. Celik).

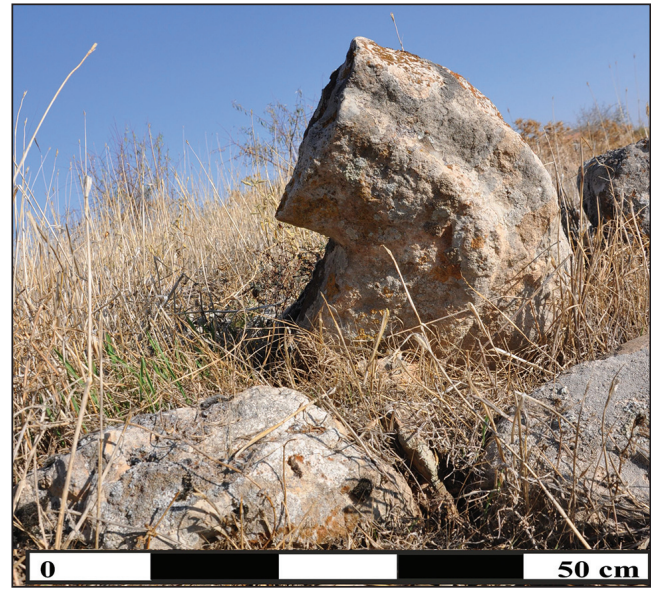

Fig. 3. A porthole stone fragment from Ayanlar Höyük (photo by B. Celik).

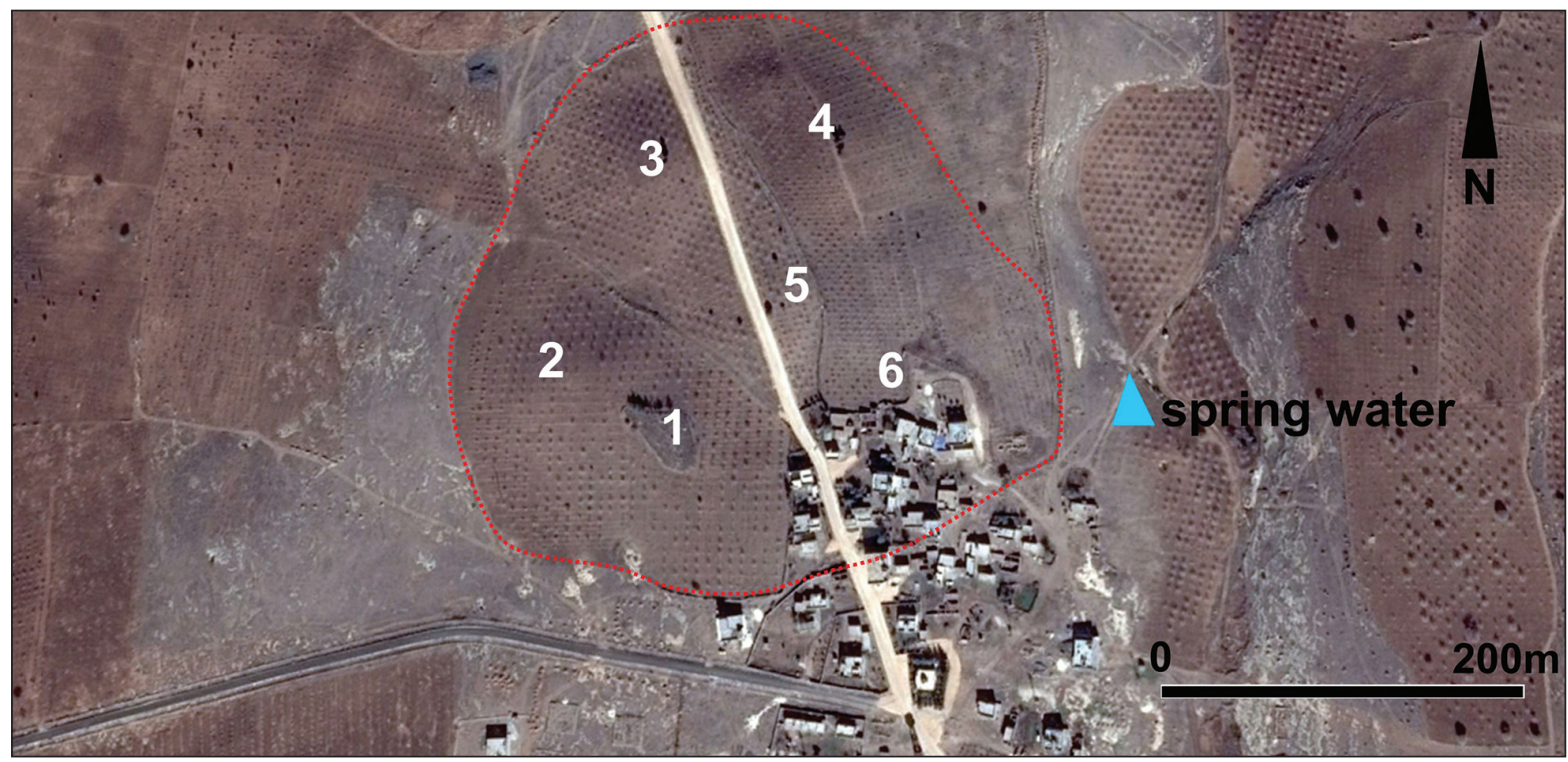

Fig. 2. Ayanlar Höyük and the hillocks located on it (created by O. Aras). 


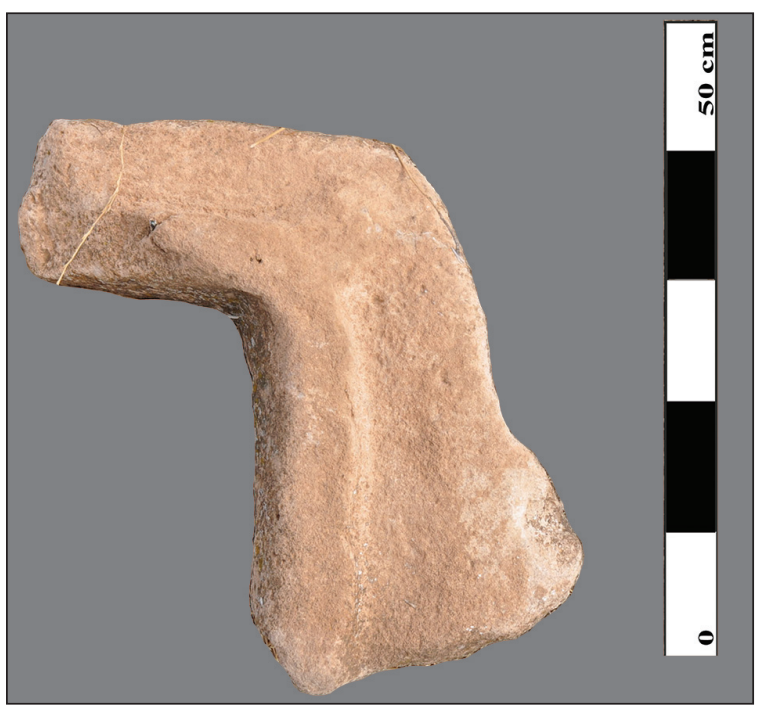

Fig. 4. A porthole stone fragment from Karahan Tepe (photo by B. Celik).

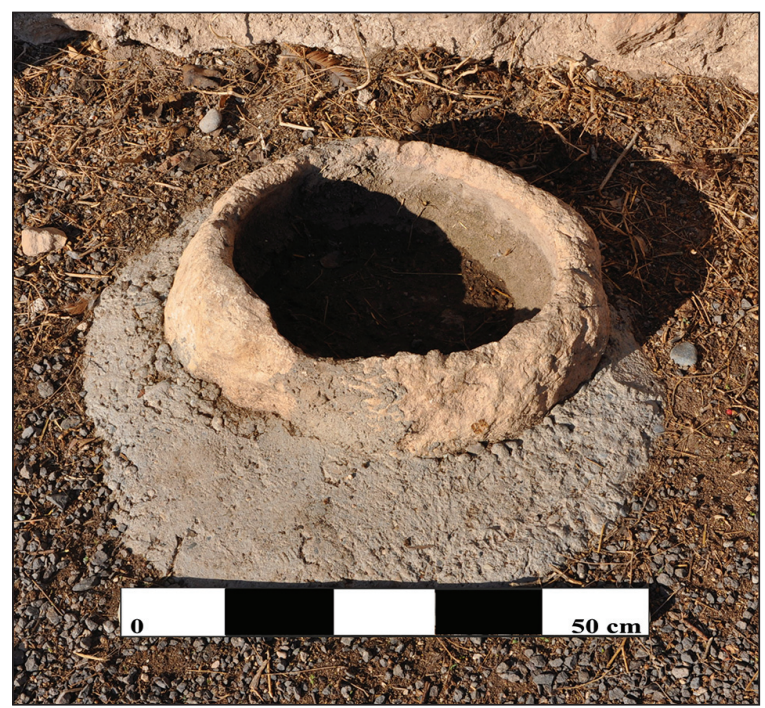

Fig. 5. Stone cube from Ayanlar Höyük (photo by B. Çelik).

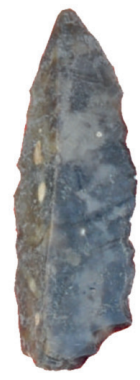

$\mathbf{a}$

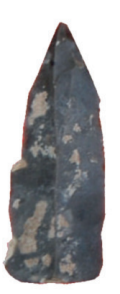

b

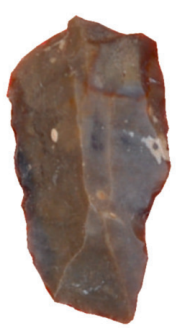

c

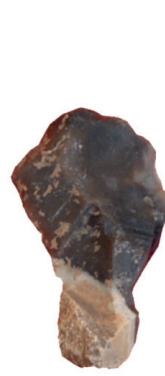

d

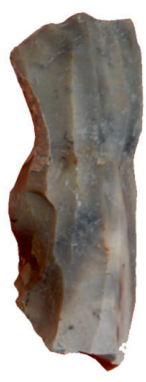

e

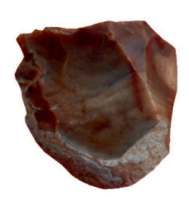

f

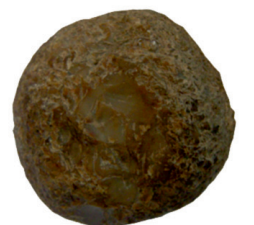

n

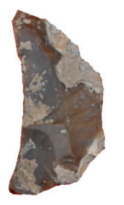

g

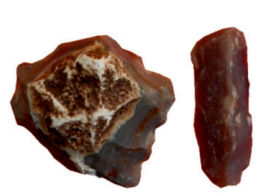

h i
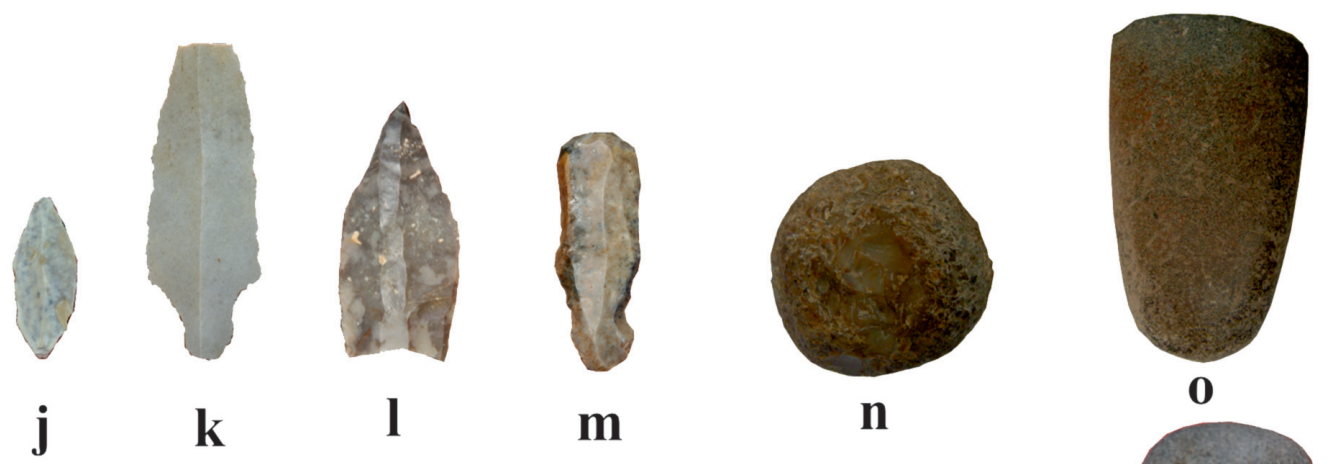

0
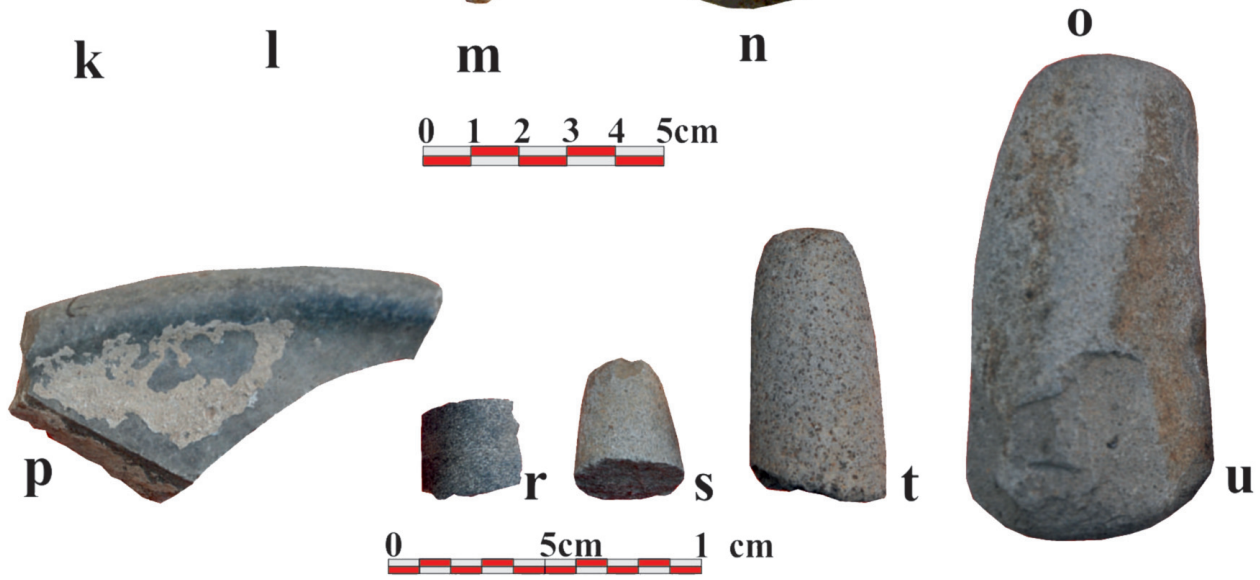

Fig. 6. Ayanlar Höyük small finds (photo by B. Çelik). 


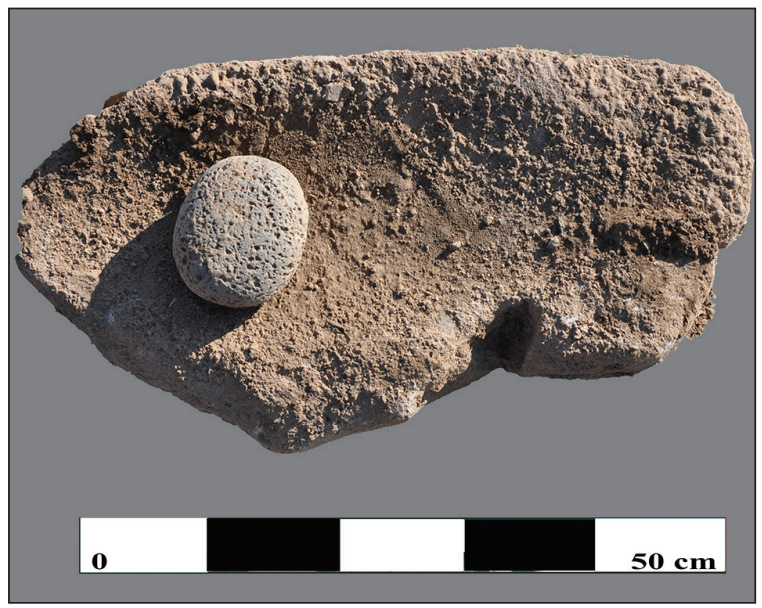

Fig. 7. Top and bottom grindstones from Ayanlar Höyük (photo by B. Celik).
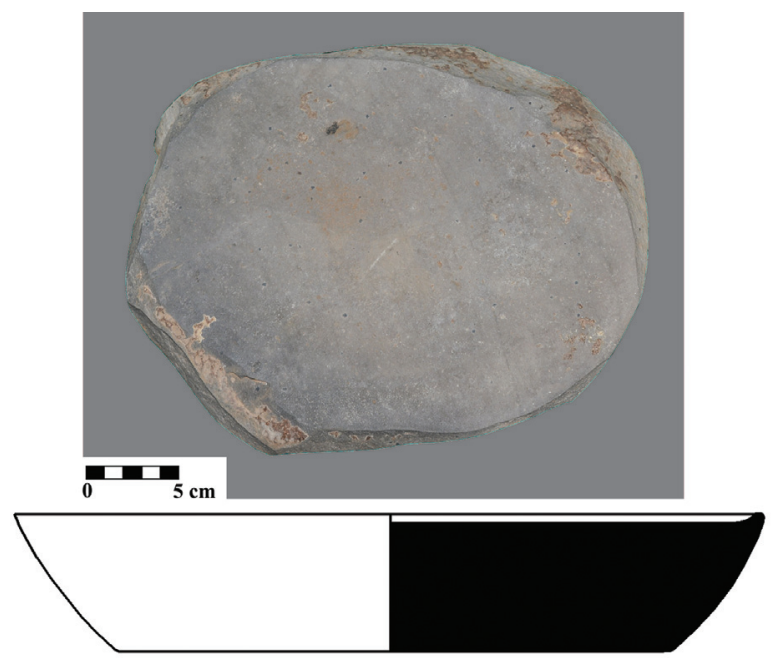

Fig. 8. Stone dish from Ayanlar Höyük (photo and drawing by B. Çelik).
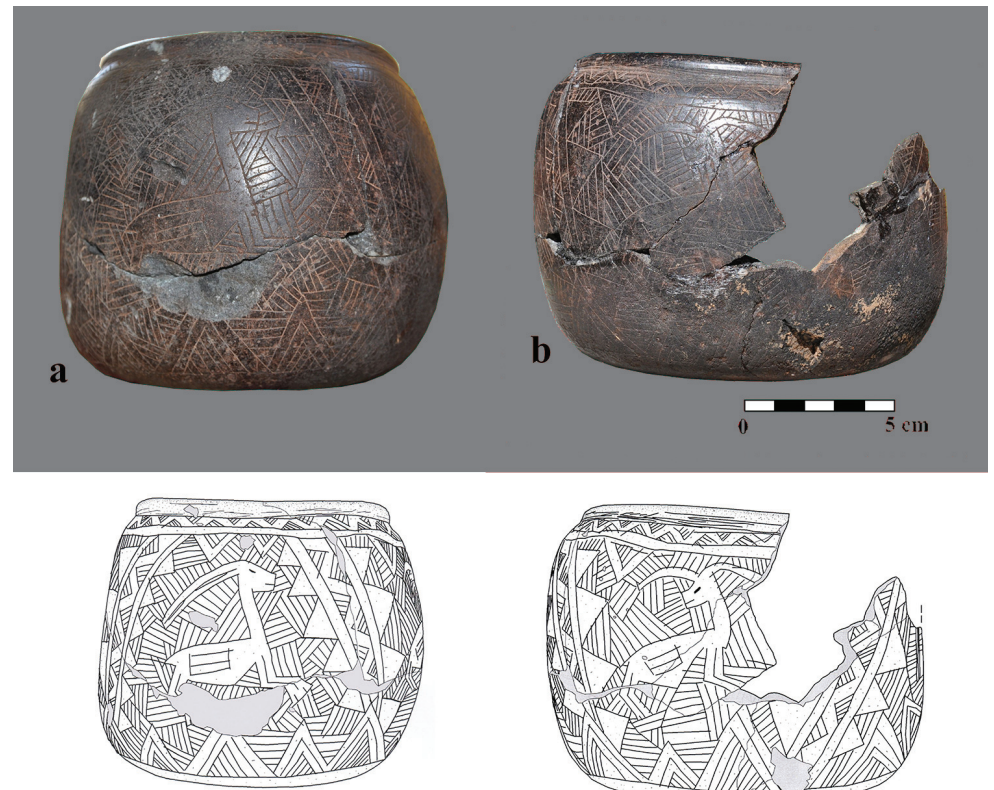

Fig. 9.a-b. Decorated stone vessel from Ayanlar Höyük (photo and drawing by B. Celik).

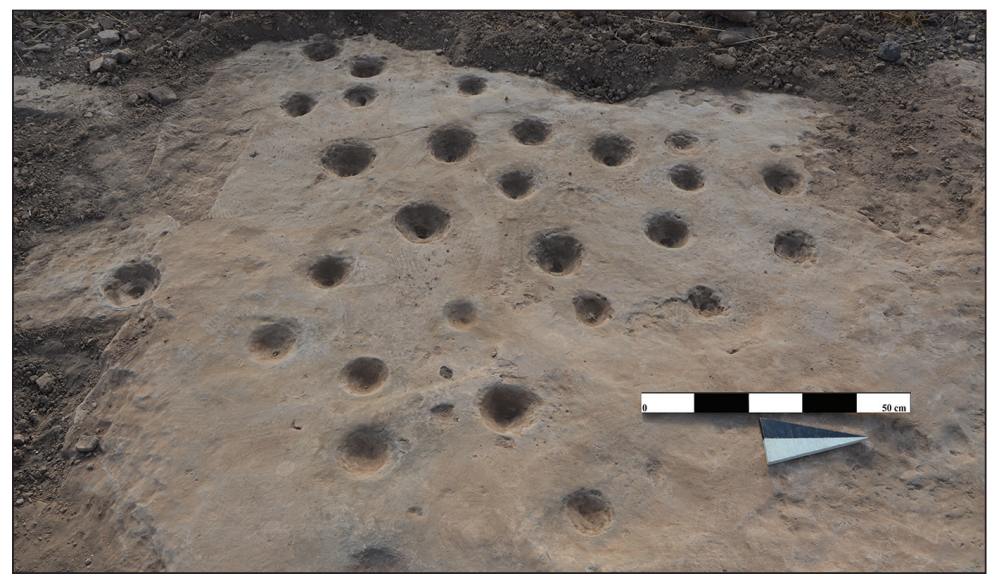

Fig. 11. Groups of hollows carved into the bedrock at Ayanlar Höyïk (photo by B. Celik).

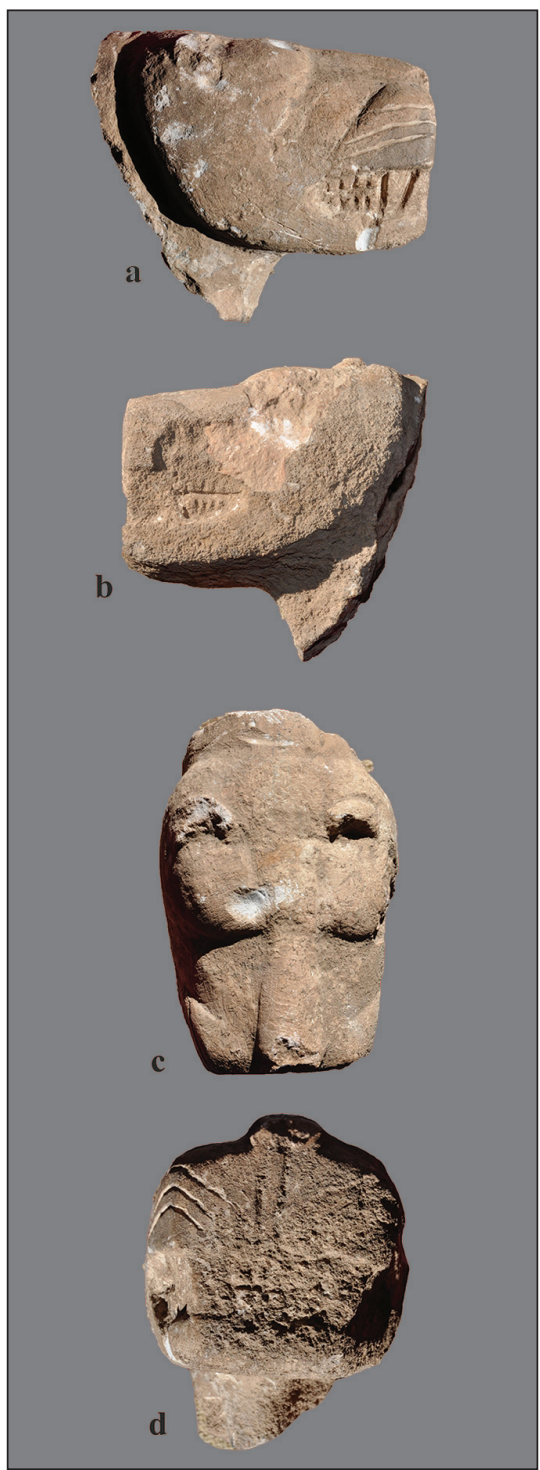

Fig. 10.a-d. Fragment of sculpture depicting the head of a leopard from Ayanlar Höyük (photo by B. Celik). 